原著論文

尿試験紙による唾液 8 成分の同時測定法の構築と残存歯の歯周病の評価

結城 健二 塚崎 弘明川和忠治芝 燁彦芝 紀代子*

\title{
Establishment of Simultaneous Measurement Method of 8 Salivary Components using Urinary Test Paper and Clinical Evaluation of Oral Environment
}

Yuuki Kenji, Tsukasaki Hiroaki, Kawawa Tadaharu, Shiba Akihiko and Shiba Kiyoko*

\section{歯科補緅学的意義}

血液に比較し，非侵襲的に採取可能な全唾液を採取し，尿一般検査で用いられている試験紙と機器を応用して，唾液中 成分 8 項目の同時測定がチェアーサイドで可能となれば，補綴装置を装着した患者自身に，唾液の検查值を通して残存 歯における歯周病の罹患状態を把握させ，理解させることができ，残存歯，特に支台歯の予後の診断・治療を進めていく うえで極めて有意義である。

抄 録

目的：歯周組織の臨床所見と全垂液中に含まれるグルコース，タンパク質，アルブミン，ビリルビン，クレ アチニン, pH, 潜血, ケトン体, 亜硝酸塩, 白血球との相関関係について比較検討した.

方法：医局員ならびに歯科治療に訪れた患者計 57 名を対象者とした。唾液採取は 1 回目として, 蒸留水 1.5 $\mathrm{ml}$ を 15 秒間口腔内で含嗽させ, 紙コップに吐き出させる. 2 回目として, 蒸留水 $1.5 \mathrm{ml}$ を 15 秒間含嗽させ, 紙コップに吐き出させる. 3 回目として，パラフィンガムを 60 秒間咀嚼させ，紙コップに吐き出させる．こ のように 3 回に分けて全唾液の採取を行った。測定法は，尿試験紙に貼り付けられた 10 項目の試薬片に, サンプルを $8 \mu \mathrm{l}$ 滴下し, 専用反射率計で計測した。歯周組織状態の判定は, 歯槽骨の吸収・プロービング值・ 動摇度・根分岐部病変を診査し，4ランクに分類した，得られた歯周病ランク別の平均值，各成分との相関 をそれぞれ統計処理した.

結果：ビリルビン，ケトン体は測定できなかった８項目の成分濃度の平均值は, 歯周病ランクが高くなる に伴って平均值も高值を示した，歯周病ランクと各成分の相関をみたところ，タンパク質，アルブミン，ク レアチニン, $\mathrm{pH}$, 白血球で相関が得られた.

結論：試験紙による唾液 8 成分の同時測定法は，支台歯および残存歯の歯周病診断に有用であることが示 唆された.

和文キーワード

唾液, 歯周病, 唾液検査, 支台歯

昭和大学歯学部歯科補緅学教室（主任：川和 忠治)

*東京医科歯科大学大学院保健衛生学研究科 (主任 : 芝 紀代子)

Department of Prothodontics, Showa University School of Dentistry

* Graduate School of Health Sciences, Tokyo Medical and Dental University

受付 : 2006 年 2 月 10 日/受理 : 2008 年 4 月 6 日

Received on February 10, 2006/Accepted on April 6, 2008 


\section{I. 緒言}

近年の高齢者の増加に伴い，義歯装着者の人口が 増加してきている．義歯の装着は口腔内の衛生環境 を悪化させることから，う蝕や歯周病に罹患する頻度 を上昇させている。唾液はその口腔内環境を予防し， 口腔内粘膜の保護 ${ }^{1,2}$ を受け持ち, さらに咬合, 咀嚼, 嚥下，発音機能を円滑に行わせると同時に，義歯の 維持安定にも寄与している ${ }^{3)}$. また唾液は血液中成分 を多く含んでおり, 歯肉溝滲出液, 白血球, バクテリ ア, 粘膜上皮細胞などと合体して口腔内の疾病状態 を反映している ${ }^{4)}$ ：この唾液中成分を検査して，歯周 組織の状態を知ることができれば，部分床義歯を装 着した患者の残存歯, 特に支台歯の予後の診断を行 う上で極めて有意義である。しかし唾液は血液と比較 して含有タンパク質の量が非常に少ないことから，唾 液中の成分分析が困難なため, 今日まであまり広く 臨床応用がされていないのが現状である．当教室では これまで歯肉の炎症と歯肉溝滲出液中の乳酸脱水素 酵素, アルカリホスタファーゼと $\beta$ グルクロニターゼ 活性が正の相関関係を示すこと ${ }^{5)}$, 唾液中のラクト フェリン濃度とプロービング值が正の相関を示すこ と ${ }^{6)}$, 部分床義歯の支台歯の歯周病診断には全唾液中 のアルブミン量が有用であること ${ }^{7)}$ を報告してきた.

そこで今回は, 部分床義歯装着後の残存歯の歯周 病診断の指標として臨床応用することを目的として, 非侵襲で採取できる全唾液を採取し, 尿一般検査で 用いられている試験紙と機器を用い, まず健常者の 唾液中成分 10 項目の測定が可能かどうかについて基 礎的検討を行った. その後, その項目について残存 歯の歯周組織状態の臨床所見と全唾液に含まれるそ れらの成分との相関関係の有無について比較検討し たので報告する.

\section{II. 材料と方法}

\section{1. 実験材料}

被験者は, 昭和大学歯学部歯科補綴学教室医局員 ならびに, 歯科治療に訪れた来院患者で本研究の主 旨を十分に理解し, 協力に同意を得られた男性 30 名 (年歯令 $24 \sim 73$ 歳), 女性 27 名 (年齢 $21 \sim 72$ 歳), 計
57 名を対象とした. なお本研究は昭和大学歯学部医 の倫理委員会の承諾を得た上で行った.

\section{2. 全唾液の採取}

まず唾液採取 1 回目として, 被験者に滅菌された 蒸留水 $1.5 \mathrm{ml}$ を 15 秒間口腔内で含嗽させ, 紙コップ に吐き出させる，以後，この方法による唾液採取法を $\lceil 1$ 回目」とする. その 30 秒後, 唾液採取 2 回目として, もう一度蒸留水 $1.5 \mathrm{ml}$ を 15 秒間口腔内で含嗽させ, 紙コップに吐き出させる，以後，この方法による唾液 採取法を「2 回目」とする. その 60 秒後, 唾液採取 3 回目として, 唾液採取用シリコンガム (Ora Sure 製) 1 個を 60 秒間咀嚼させ, 紙コップに吐き出させる. 以後, この方法による唾液採取法を「3 回目」とする. このように 3 回に分けて全唾液の採取を行った.

\section{3. 歯周組織状態の判定}

唾液の採取後, 残存歯の歯槽骨の吸収の程度・プ ロービング值（歯肉溝の深さ, 歯周ポケットの深さ: $\mathrm{PD})$ ・歯の動摇度・根分岐部病変の有無を診査し, $\mathrm{P} 0 \sim \mathrm{P} 3$ までの 4 ランクに分類し, 歯周組織状態の評 価を行った。 P0 は歯槽骨の吸収がほとんど認められ ず，歯周ポケットが $2 \mathrm{~mm}$ 以下，歯の動摇度が 0 ～ 度, 根分岐部病変が認められない歯周組織状態, P1 は歯槽骨の吸収が歯根長の $1 / 3$ 以下, 歯周ポケット が 3 5 mm, 歯の動摇度が $0 \sim 1$ 度, 根分岐部病変 が認められない歯周組織状態，P2 は歯槽骨の吸収が 歯根長の $1 / 3 \sim 1 / 2$, 歯周ポケットが $4 \sim 7 \mathrm{~mm}$, 歯の 動摇度が $1 \sim 2$ 度, 根分岐部病変が 1 度の歯周組織状 態, P3 は歯槽骨の吸収が歯根長の $1 / 2$ 以上, 歯周ポ ケットが $6 \mathrm{~mm}$ 以上, 歯の動摇度が 2 3 度, 根分岐 部病変が $2 \sim 3$ 度の歯周組織状態とした。 歯槽骨の吸 収の程度, 根分岐部病変の有無の審査には, パノラ マエックス線写真を用い, プロービング值の計測は 6 点計測法を用いた。

\section{4. 全唾液中成分の測定}

全唾液中成分の測定項目は, グルコース, タンパ ク質, アルブミン, ビリルビン, クレアチニン, $\mathrm{pH}$, 潜血, ケトン体, 亜硝酸塩, 白血球の 10 項目とした. 測定方法は，尿成分の一般検査に用いられている尿 試験紙（オーションスティックス，アークレイ（株） 

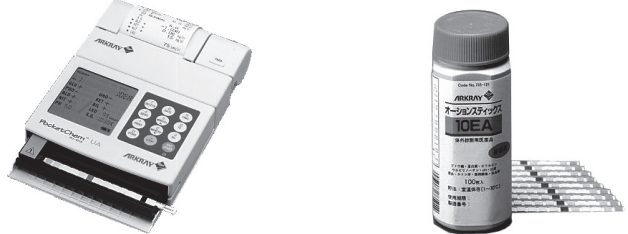

図 1 Specific reflectometer and urinary test paper 専用反射率測定器と尿試験紙

表 1 Measurement wavelength of each measurement items 各測定項目の測定波長

\begin{tabular}{ccc}
\hline \hline $\begin{array}{c}\text { Measurement } \\
\text { items }\end{array}$ & $\begin{array}{c}\text { Measurement } \\
\text { wavelength } \\
\text { (nm) }\end{array}$ & $\begin{array}{c}\text { Reference } \\
\text { wavelength } \\
\text { (nm) }\end{array}$ \\
\hline Glucose & 635 & 760 \\
Protein & 635 & 760 \\
Albumin & 565 & 760 \\
Bilirubin & 565 & 760 \\
Creatinine & 635 & 760 \\
pH & 565 & 760 \\
BLD & 635 & $=$ \\
KET & 565 & 760 \\
NIT & 635 & 760 \\
LEU & 565 & 760 \\
\hline
\end{tabular}

BLD: Occult blood, KET: Ketone body, NIT: Nitrite, LEU: Leukocyte

に貼り付けられた測定対象成分 10 項目の試薬片に, 採取直後の唾液サンプルをそれぞれ $8 \mu 1$ 滴下し，よ く浸透させ，室温で 60 秒間反応させた後に，専用反 射率計 [Pocketchem UA，アークレイ(株)］で反射 率を計測した（図 1)。その測定方法の原理は 2 波長 反射測光法であり, 測光部ではマルチ LED から 2 波 長の光が試験紙の反応部に照射され，その反射光を 検出器で受光する方法である (表 1 )。処理能力は 1 時間 50 テストである.

次に, 各項目について反射率から検量線を作成し, 濃度換算するが，そのときの対象となる定量法は，グ ルコースは GOD 電極法, タンパク質はピロガロール レッド法, アルブミンは免疫比濁法, ビリルビンは柴 田変法,クレアチニンは酵素法, $\mathrm{pH}$ は $\mathrm{pH}$ 電極法, 潜 血，ケトン体，亜硝酸塩は添加した標準物質から濃度 を算出，白血球は Fuchs-Rosenthal 計算盤を用いた。

\section{5. 統計学的解析}

残存歯の歯周病ランクと全唾液中成分中測定可能 であった 8 項目(グルコース, タンパク質, アルブミン,
表 2 Measurable range of urinary test paper 試験紙の感度

\begin{tabular}{cr}
\hline \hline Items & Measurable range \\
\hline Glucose & $0 \sim 1,000 \mathrm{mg} / \mathrm{dl}$ \\
Protein & $0 \sim 300 \mathrm{mg} / \mathrm{dl}$ \\
Albumin & $0 \sim 20 \mathrm{mg} / \mathrm{dl}$ \\
Bilirubin & $0 \sim 10 \mathrm{mg} / \mathrm{dl}$ \\
Creatinine & $0 \sim 300 \mathrm{mg} / \mathrm{dl}$ \\
pH & $5 \sim 9-$ \\
BLD & $0 \sim 1 \mathrm{mg} / \mathrm{dl}$ \\
KET & $0 \sim 50 \mathrm{mg} / \mathrm{dl}$ \\
NIT & $0 \sim 2 \mathrm{mg} / \mathrm{dl}$ \\
LEU & $0 \sim 250 \mathrm{leu} / \mathrm{ul}$ \\
\hline
\end{tabular}

BLD: Occult blood, KET: Ketone body, NIT: Nitrite, LEU: Leukocyte

クレアチニン, 潜血, $\mathrm{pH}$, 亜硝酸塩, 白血球）の濃 度について一元配置分散分析法を行い，有意な差が あったものに関してはその後, Scheffe 法を行った。 また, 歯周病ランクと全重液中成分 8 項目の濃度と の相関関係をスピアマンの順位相関係数を用いて統 計処理を行った。 $p \leqq 0.05$ を有意差ありとした.

\section{III. 結 果}

\section{1. 健常者の全唾液中成分の測定条件}

蒸留水 $1.5 \mathrm{ml}$ を 15 秒間口腔内で含嗽させ, 紙コッ プに吐き出させる採唾法では，唾液サンプルが速やか に試験紙に浸透し，尿試験紙 10 項目を 60 秒間で簡 便に測定することができた

同じ歯周病ランクであっても, 全唾液採取 1 回目, 2 回目, 3 回目の唾液中成分の測定結果において差が 認められた。

\section{2. 試験紙の感度}

各唾液サンプルを試験紙に浸透させ専用反射率計 で反射率を測定した結果，試験紙の 10 項目のうち 8 項目, 即ちグルコース, タンパク質, アルブミン, クレ アチニン, $\mathrm{pH}$, 潜血, 亜硝酸塩, 白血球 (エラスター ゼ活性）は測定可能であった。しかしながら，ビリル ビン, ケトン体の 2 項目は唾液中に微量にしか存在 しないため, 2 項目ともどの検体も全く発色しなかっ たので測定項目から除外した（表 2). 
表 3 The mean values in each periodontal disease rank 歯周ランク別の平均値

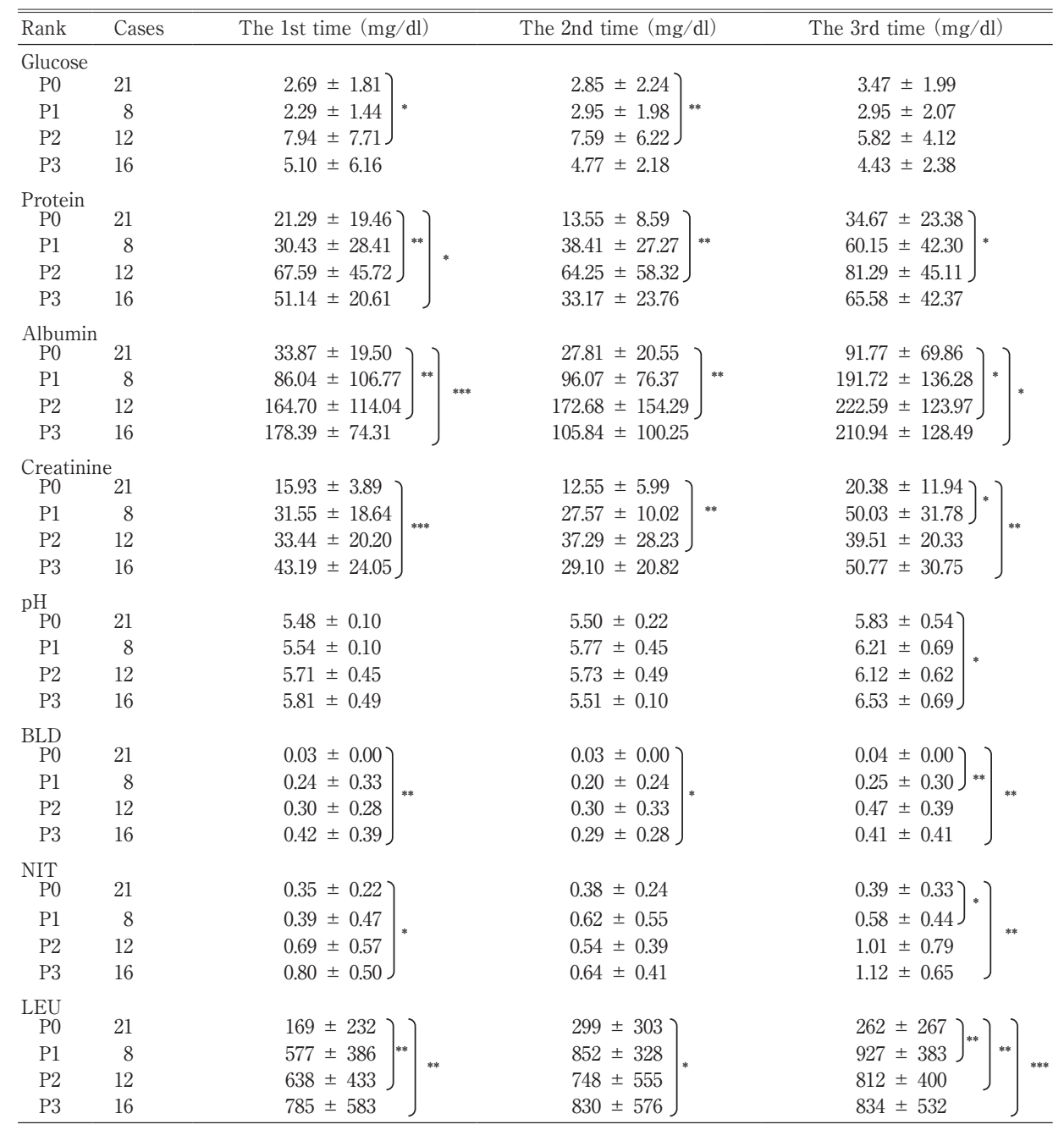

BLD: Occult blood, KET: Ketone body, NIT: Nitrite, LEU: Leukocyte

*** $p \leqq 0.001,{ }^{* *} p \leqq 0.01,{ }^{*} p \leqq 0.05$

\section{3. 残存歯の歯周病ランク別にみた唾液中成分濃度} 残存歯の歯周病ランクと全唾液中成分中測定可能 である 8 項目（グルコース, タンパク質, アルブミン, クレアチニン, 潜血, $\mathrm{pH}$, 覀硝酸塩, 白血球) の濃度 について一元配置分散分析法を行い，有意な差が あったものに関してはその後, Scheffe 法を行った.

グルコースでは, 有意差がみられたのは 1 回目, 2 回 目の唾液においてのみであった。タンパク質では, 1 回目の唾液において $\mathrm{P} 0$ に対して P2, P3 が. 2 回目, 3 回目の唾液においては $\mathrm{P} 0$ に対して $\mathrm{P} 2$ が有意に高值 であった.アルブミンでは 1 回目， 3 回目の唾液にお いて P0 に対して P2 および P3 が, 2 回目の唾液におい て $\mathrm{P} 0$ に対して $\mathrm{P} 2$ が有意な差で高值であった. クレア
チニンでは 1 回目の唾液において P3 が P0 に対して, 2 回目では P2 が P0 に対して, 3 回目では P1, P3 が $\mathrm{P} 0$ に対して有意に高值であった. $\mathrm{pH}$ では, 1 回目, 2 回目の唾液においては有意な差は認められなかった が，3回目の唾液において，P3 が P0 に対して有意に 高值であった。潜血では 1 回目, 2 回目の唾液において P3 が P0に, 3 回目の唾液においては $\mathrm{P} 2, \mathrm{P} 3$ が $\mathrm{P} 0$ に 対して有意に高值であった。亜硝酸塩では 1 回目の 唾液において P3 が P0に，3 回目の唾液においては P2，P3 が P0 に対して有意に高值であった．白血球数 では 1 回目の唾液において P2, P3 が P0 に, 2 回目の 唾液において $\mathrm{P} 3$ が $\mathrm{P} 0$ に, 3 回目の唾液において $\mathrm{P} 1$, P2，P3 が P0 に対して有意に高值であった（表 3). 

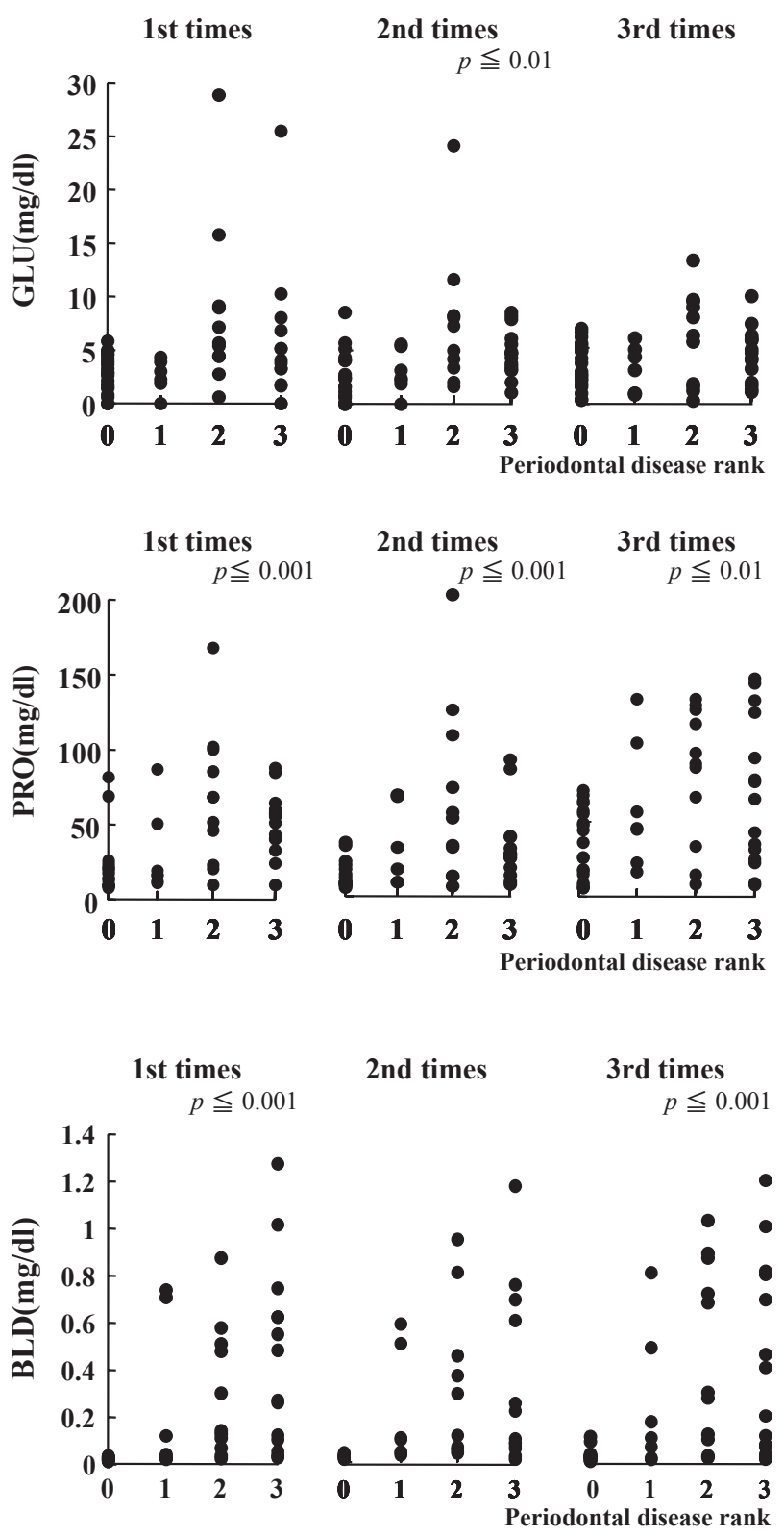

1st times

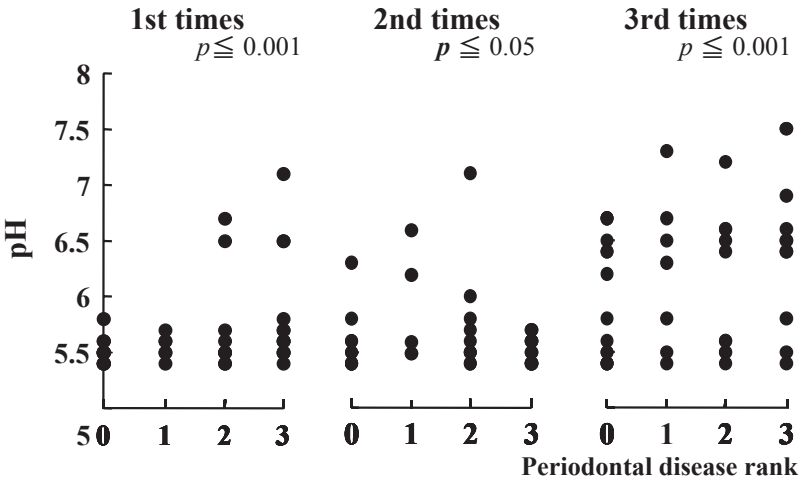

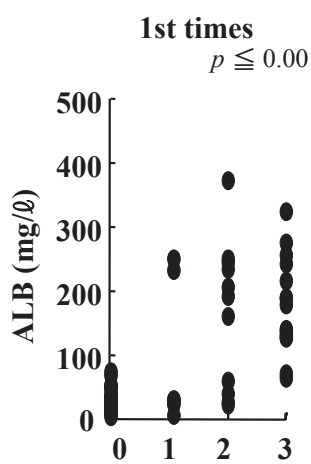

1st times

$$
p \leqq 0.001
$$
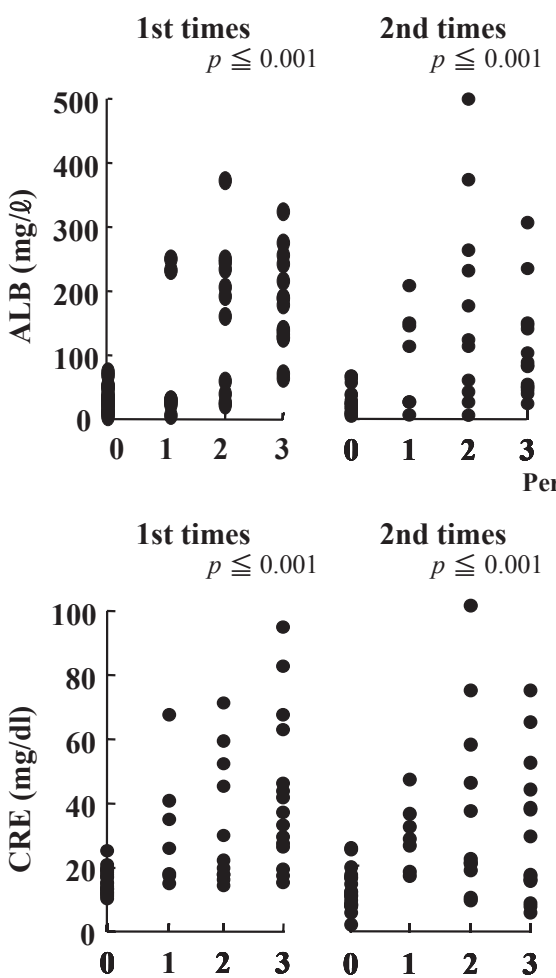

3rd times

$p \leqq 0.001$

\section{-}

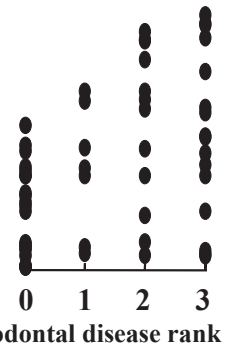

2nd times

3rd times

-

- $p \leqq 0.001$

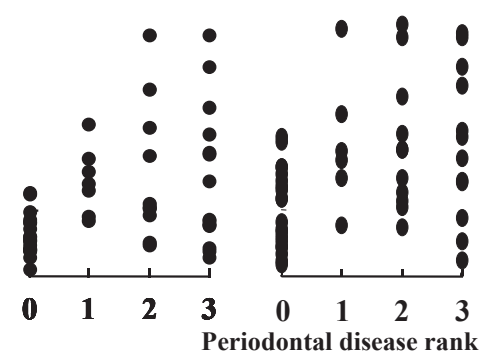

2nd times

3rd times

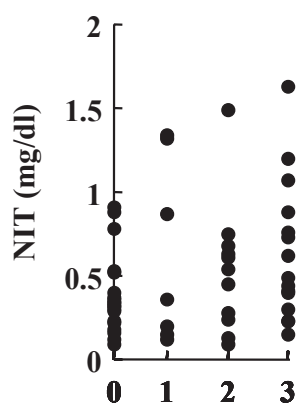

$8: 8:$

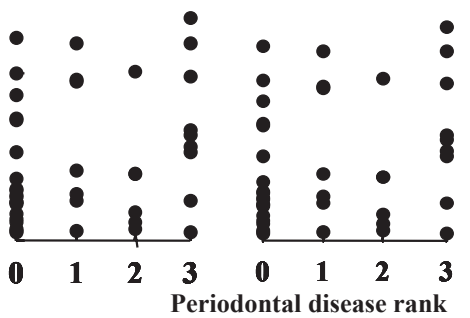

1st times

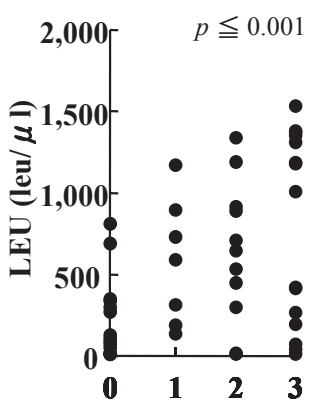

2nd times

3rd times

$p \leqq 0.01$

$p \leqq 0.01$

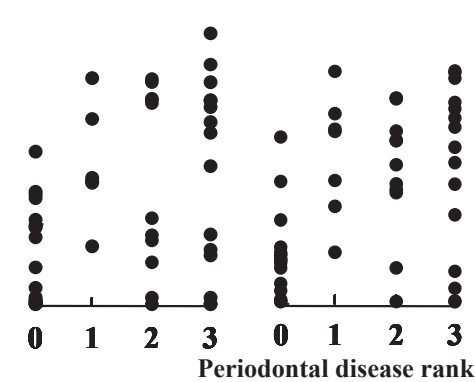

図 2 Correlation between the periodontal disease ranks and the components

GLU: Glucose, PRO: Protein, ALB: Albumin, CRE: Creatinine, BLD: Occult blood, NIT: Nitrite, LEU: Leukocyte

歯周ランクと各成分值の相関 


\section{4. 残存歯の歯周病ランクと全唾液中成分濃度との 相関関係}

残存歯の歯周病ランクと全唾液中成分 8 項目（グ ルコース, タンパク質, アルブミン, クレアチニン , 潜 血, $\mathrm{pH}$, 覀硝酸塩, 白血球) の濃度との相関関係を スペアマンの順位相関分析法でみた。グルコースでは 2 回目の唾液においてのみ $p \leqq 0.01$ で歯周病ランクと 測定值の間に相関が認められた。 タンパク質では 1 回 目, 2 回目の唾液において $p \leqq 0.001$ で, 3 回目の唾 液において $p \leqq 0.01$ で歯周病ランクと測定值の間に 相関が認められた.アルブミンでは, 1 回目, 2 回目, 3 回目の唾液において $p \leqq 0.001$ で歯周病ランクと測 定值の間に相関が認められた. クレアチニンでも 1 回 目, 2 回目, 3 回目の唾液において $p \leqq 0.001$ で歯周 病ランクと測定值の間に相関が認められた。潜血で は 1 回目, 3 回目の唾液において $p \leqq 0.001$ で歯周病

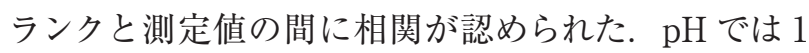
回目, 3 回目の唾液において $p \leqq 0.001$ で, 2 回目の 唾液において $p \leqq 0.05$ で歯周病ランクと測定值の間 に相関が認められた．亜硝酸では 1 回目, 2 回目, 3 回目ともに歯周病ランクと測定值の間に相関が認めら れなかった. 白血球数では 1 回目の唾液において $p \leqq$ 0.001 で, 2 回目, 3 回目の唾液において $p \leqq 0.01$ で歯 周病ランクと測定值の間に相関が認められた(図 2 ).

\section{IV. 考察}

歯周病の診査・検査で現在行われている歯肉の状 態（視診およびプローブなどによる GI，BO などの検 査), 歯根膜の破壊状態（プローブによるポケット検 査), 骨の吸収状態 (エックス線写真像による判定) などは, 診査時の残存歯の歯周組織状態を示してい るに過ぎず，検査がその治療に対してどのような予知 性を持ち, その後の治療に如何に貢献するかは重要な 問題である. 歯周病の検査は歯ごとの検査が重要で あるが, 一方で口腔内全体における歯周組織の状態 を把握する検査も大切である，チェアーサイドで簡便 に唾液検査を行い，唾液中成分を数值化することが 可能になれば, 自覚症状のない患者に対しても情報 提供・インフォームドコンセントを通じて, 検査結果 から歯周病罹患度を説明し, 支台歯や残存歯の術後 管理ならびに歯周病治療の必要性を理解させ, 治療
を早期に行うことが容易となることから, 装着した義 歯および補緅物の長期管理にもつながる.

そこで, 著者らは今回簡便な機器を用いて短時間 で唾液中成分を測定できる方法を検討し，一般尿検 査に用いられている試験紙を応用することにした。一 般的に尿検査で用いられる試験紙は短冊状のプラス チック片に試薬を含ませた滤紙（反応部分）が貼り 付けてあり, 多用されているものは 10 項目の尿中成 分を測定する複合試験紙である ${ }^{8)}$. 用手法で行う場合, コップに約 $50 \mathrm{ml}$ の尿を採取し，その中に尿試験紙 を浸して直ちに引き上げ, 規定の時間反応させた後, 各試験片部分の呈色と添付の色調表を比較しながら 判定を行う。しかし, 唾液は尿と比較して試料を多 量に採取することが困難なため, 各試験紙片に試料 を点着する方法を模索した．各試験紙片に試料を点 着する際，問題となるのは唾液の粘性である，唾液 は粘性があるために正確に試料を採量することが難 しく, 唾液中成分の正確な值を計測することが困難 であった，そのため本実験では $1.5 \mathrm{ml}$ の蒸留水を口 腔内で含嗽させ，唾液を希釈した状態で採取するこ とにした。この方法は唾液の粘性を減じることができ， 試験片への浸透をより容易にすることが可能となっ た。また，唾液採取 1 回目では，口腔内の食物残椬 等が採取唾液に含まれることが予期され，2 回目では それらが減じることによる測定結果の差異を検討する ため，1，2回目の採唾法を用いた。ささらに，1，2 回 目の採唾法では無刺激な歯周組織状態が測定結果に 反映しやすく, 3 回目ではパラフィンガムを咀嚼する ことにより, 残存歯や歯周組織に刺激が加わり, 歯肉 溝内および歯周ポケット内の内容物が採取唾液中に 含まれることが予期されるので，唾液採取を 3 回に分 けて実験を行った。

次に測定機器であるが, 従来の尿検査では検査室 で測定を行う場合，すべての工程を全自動で行う全自 動測定装置が用いられているが，本研究では簡便に チェアーサイドで測定可能な機器として, Pocketchem UA を採用した。この Pocketchem UA は小型で使 用方法が容易で，短時間で測定が可能なので，この 機器を用いて唾液中成分の反射率の測定を行った. その結果，尿試験紙に貼付している 10 測定項目のう ち, 8 項目が測定可能となった. 測定結果についてみ ると, グルコースでは 2 回目のみ歯周ランクと数值の 
間に相関が認められた。柴崎らは全唾液中のグルコー 又量の増加は歯垢形成を促進させ, 歯周病に罹患し やすい状態をつくると報告している ${ }^{9)}$. 本研究結果に おいても 1,3 回目の P1 は P0 よりもわずかにグルコー スの量が減少したが，P2 は P0 と比較して増加傾向 を示し， 1，2 回目採唾の P0 と P2 の間には有意差が 認められた。この結果からグルコースの量の増加と歯 周病の重症度との間に何らかの関連があることが推 測された.タンパク質とアルブミンは，1，2，3 回目 すべてにおいて歯周病ランクとの間に相関関係が認め られた。 木村は健常者と歯周炎患者の夕ンパクを電 気泳動法を用いて比較検討し, 両者の間に有意差は みられなかったが，歯周炎患者は高值傾向を示し， またアルブミン分画でも高值を示したと報告してい る ${ }^{10)}$. 総タンパク濃度の増加は, 歯周ポケット内に 含まれる細菌由来の高分子物質が上皮細胞間を通過 し, 基底膜に達して高濃度になると浸透圧勾配が生 じ，組織液が上皮細胞間隙から歯周ポケット内へ流 出する. さらに炎症ケミカルメディエーターにより血 管透過性が立進していく，このようにして生じた歯肉 溝渗出液には血清タンパク質を多く含むようになる. Henskens らは, 健常者の総タンパク濃度は平均約 $1,000 \mathrm{mg} / \ell$, 歯肉炎患者は平均約 $2,200 \mathrm{mg} / \ell$ を示す

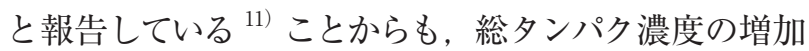
は歯肉溝滲出液の混入によるものと考えられる，高橋 らは歯周ポケットの深い歯が多く存在すると全唾液 中のアルブミン量が増加することが判明したと報告し ている ${ }^{7)}$. Meechanら, Basuらも感染から生じた炎症 反応と炎症から生じた歯周組織の破壊によって唾液 中のアルブミン濃度が上昇すると報告している ${ }^{12,13)}$. それらは本研究の結果と一致している. Shannon らは 歯周病患者の血清中の総タンパク濃度, アルブミン, 免疫グロブリン，尿酸值は正常であると報告してい る ${ }^{14,15)}$. また Cattoni らは電気泳動による分析で血清 中の総タンパク, $\mathrm{Alb} \cdot \alpha_{1} \mathrm{G} \cdot \alpha_{2} \mathrm{G} \cdot \beta-\mathrm{G} \cdot \gamma-\mathrm{G}$ 分画は 進行した歯周病患者でも正常範囲内にあると報告し ていることからも ${ }^{16)}$, 血中アルブミン濃度は増加しな い. 従って増加した血中アルブミンが唾液腺から流 出してきたのではなく，アルブミンを含む血中成分の 歯肉溝滲出液中への滲出により歯周病患者群の唾液 中アルブミン濃度が増加したものといえる. 本研究に おいても P2, P3 のアルブミン濃度が，P0 に比較して
有意に高かったことからも, アルブミンが歯周病の重 症度を反映しているものと考えられる. クレアチニン も 1, 2, 3 回目すべてにおいて歯周病ランクとの間に 相関が認められた。 クレアチニンは蛋白質代謝から生 じたアミノ酸であるアルギニンが肝臓内で合成され， クレアチンになる. クレアチンは筋細胞内に取り込ま れ, 筋肉, エネルギー代謝に利用され, その代謝最終 産物としてクレアチニンが生じる ${ }^{15)}$. 唾液中のクレア チニンについて論じられた論文はみつからなかったの で, その作用機序については解明できなかったが，何 故歯周病ランクとクレアチニン值に相関が認められる のか, 興味ある知見である. $\mathrm{pH}$ も歯周病ランクとの 間において，1，2，3 回目ともに相関が認められた。 鶴田らは唾液中の $\mathrm{pH}$ が高くなると歯石沈着が起こ りやすい口腔環境になり, 歯周疾患に罹患するリスク が高いと考えられると報告している ${ }^{17)}$. 内藤らは in vitroにおいて, 低い $\mathrm{pH}$ ではグラム陰性嫌気性菌の 増殖はほとんど認められないが, $\mathrm{pH}$ が高くなるにつ れてグラム陰性嫌気性菌が増殖し, 歯周組織の炎症 と唾液 $\mathrm{pH}$ との間には有意な相関があると報告してい るが ${ }^{18)}$ ，それらの見解と本研究の結果は一致してい た. 唾液 $\mathrm{pH}$ が高くなると, 歯周疾患に罹患するリス クが高いと考えられる. 潜血・白血球数についてみる と, Klink hamer らは歯肉溝から口腔内へ遊走した白 血球数が歯周組織の炎症の指標として有用であると提 唱しており ${ }^{19-22)}$, Woolweaver らは白血球数と歯肉 炎の程度との間に相関関係が認められたと報告して いる ${ }^{23)}$. また野村らは, 尿中潜血検査紙を利用して 唾液中の血液量を測定し，歯肉炎症との間に相関関 係が認められたと報告していることから, 潜血・白血 球数は歯周病の検査に有用であるといえる。内田ら は混合唾液を採取し, 被験者を歯肉からの出血・排 膿・発赤・腫脹, 歯の動摇, 歯周ポケットの哚さ, 歯 槽骨の吸収によって分類し, 潜血・白血球数を測定 した結果, 唾液中の白血球数は歯周炎の程度に比例 して増加し, 特に歯の動摇, 歯槽骨の吸収度に比例 して増加した。 また唾液中の潜血量は歯周病との相 関は認められず，歯肉発赤との間に強い関係がみられ た.さらに唾液中の潜血量と白血球数との間には相 関関係が認められなかったが，唾液中の潜血量は浅在 性の歯肉炎すなわち歯肉辺縁における炎症の程度の 評価に, 白血球数は哚在性の歯周病の評価に適して 
いると考えられると報告している ${ }^{24)}$.また中村らは歯 周ポケットの有無と唾液中の白血球との関係を検査 し, 白血球は歯周炎群（歯周ポケットの媣さ $4 \mathrm{~mm}$ 以 上）が健常群に比較して有意に高いと報告している ${ }^{25)}$. 白血球数は本研究でも, $1,2,3$ 回ともに歯周病ラン クとの間に有意な相関関係が認められ，また第 1 回目 の唾液では $\mathrm{P} 0$ よりも $\mathrm{P} 2, \mathrm{P} 3$, 第 2 回目では $\mathrm{P} 0$ より も P3, 第 3 回目では P0 よりも P1, P2, P3 と白血球 数が明らかに増加している. 白血球数の増加は歯肉溝 中の白血球がその Lysosomal enzymeにより炎症を 惹起するとの証拠があり，また歯垢および歯石を除去 すると, Chemotactic factor の除去により白血球の歯 肉溝への遊走が減少するとの報告もあることから, 白 血球数の測定は歯周病の診査・検査に有用であると 考える. 潜血は 1,3 回目が歯周病ランクとの間に有 意に高い相関関係が認められた。 2 回目は相関関係 が認められなかったが， $1 ， 2 ， 3$ 回目ともに $\mathrm{P} 0$ の值 よりも, P3 は明らかに増加しており, 3 回目では P0 と $\mathrm{P} 3$ のほか $\mathrm{P} 2$ との間にも有意な差異が認められた。 内田らは, 潜血量は潜在性の歯肉炎の程度を評価し, 深在性の歯周病の評価はできないと報告しているが, 本研究結果とは一致しなかった。しかし歯周病の進行 により歯周ポケット中にも歯肉側からの出血は生じる ので, この相違は測定法の相違によるものと考察され， 本研究の結果から, 潜血も歯周病の重症度を反映す ると考える.

本研究によりタンパク質, アルブミン, クレアチニン, $\mathrm{pH}$, 潜血, 白血球は残存歯および支台歯の歯周組織 疾患の診断・評価法に応用できる可能性が示唆され, この方法は集団検診における歯周病のスクリーニング 法にも適したものであると考える。

\section{V. 結 論}

全唾液を尿一般検査に用いられている試験紙と機 器を用いて分析し，唾液中に含まれている成分と歯 周組織の臨床所見との相関関係の有無について比較 検討し, 以下の結論を得た。

1. 全唾液の採取法と全唾液中成分の測定条件を確立 した。

2. 健常者唾液を用いて, グルコース, タンパク質, アルブミン，ビリルビン，クレアチニン， $\mathrm{pH}$ ，潜血，
ケトン体, 亜硝酸, 白血球を測定した結果, ビリ ルビンとケトン体は検出感度以下で測定できな かったが，残りの 8 項目は測定可能であった。

3. 測定可能な 8 項目の唾液中成分濃度の平均值は歯 周病ランクが高くなるにしたがって高值を示し た. P0 との有意な差異はすべてに認められたが, 一定の傾向はみられなかった。

4. 3 回測定した 8 項目の各成分と歯周病ランクの相関 関係をみたところ，3 回採唾とも良好な相関が認め られたのはタンパク質, アルブミン, クレアチニン， $\mathrm{pH}$, 白血球，2回採唾で認められたのは潜血，1 回採唾のみはグルコース，すべて認められなかった のは亜硝酸であった.

5. 測定可能であった 8 項目は, 残存歯の歯周組織の 状態を反映しているので, 臨床応用可能であるこ とが示唆された。

\section{文献}

1) Dowd FJ. Saliva and dental caries. Dent Clin North Am 1999; 43: 579-597.

2) Kaufman E, Lamster IB. A review. Analysis of saliva for periodontal diagnosis. J Clin Periodontol 2000; 27: 453-465.

3）芝 燁彦．義歯床の維持と口蓋腺に関与する唾液蛋白に ついて 第 1 報 アガロース等電点電気泳動法による唾液 蛋白分析の基礎的検討. 補緅誌 1986; 30: 948-953.

4) Edgar WM. Saliva: its secretion, composition and functions. Br Dent J 1992; 172: 305-312.

5）小渓徹彦. 歯肉溝渗出液中の酵素活性と臨床的指標と の関係について．昭歯誌 1993; 13: 422-432.

6）木村江美子．唾液中のラクトフェリンと蛋白分画に関す る研究 昭歯誌 2001; 21: 267-278.

7）高橋幸子. 有歯顎者, 無歯顎者および歯周病患者の全唾 液総蛋白濃度と蛋白分画の比較。補緅誌 2004; 48: 723732.

8）星 和夫, 鈴木敏恵. III. 尿定性試験紙の取り扱い 臨 床検査学講座 臨床検查総論第 IV 章 2004; 51-53, 東京： 医歯薬出版.

9）柴崎貞二. 最新糖尿病マニュアル 糖尿病患者にみられる 合併症 糖尿病と歯周病.エキスパートナース 2001; 17: 127-130.

10）木村江美子．唾液中のラクトフェリンとタンパク分画に 関する研究. 昭歯誌 2001; 21: 267-278.

11) Henskens YMC, Velden U, Veerman ECI et al. Protein, albumin and cystatin concentrations in saliva of healthy subjects and of patients with gingivitis or peri- 
odontitis. J Periodont Res 1993; 28: 43-48.

12) Meechan JG. Salivary albumin concentration and periodontal disease. J Dent Res 1983; 62: 439.

13) Basu MK, Smith AJ, Walsh TF et al. Albumin in saliva during experimentally induced gingivitis. J Dent Res 1984; 63: 514.

14) Dawes $C$. The effects of flow rate and duration of stimulation on the concentrations of protein and the main electrolytes in human submandibular saliva. Arch Oral Biol 1974; 19: 887-895.

15) Edger WM, O'Mullane DM（河野正司). Saliva and oral health（唾液一歯と口腔の健康 1997; 31-46, 東京: 医歯 薬出版) , 1990

16）新臨床検查技師教育研究会．臨床検査の知識の整理 臨 床化学 2004; 207-209, 東京: 医歯薬出版。

17）鶴田圭伊子。口腔環境が細菌叢へ及ぼす影響について - 唾液 $\mathrm{pH}$ と縁上縁下細菌との関係。口衛誌 2001; 51: 378-379.

18）内藤浩美, 大橋一之, 神部芳則ほか，長期経管栄養者に おける口胿環境に対する検討 - 唾液 $\mathrm{pH}$ と歯周疾患罹患 状況. 咽頭細菌について-。日本口腔科学会雑誌 2003; 52: 181-187.

19）大島光宏．新しい唾液潜血試験紙法による歯周疾患のス クリーニング試験の有用性. 日歯周誌 2001; 43: 416-423.
20) Klinkhamer JM. Quantitative evaluation of gingivitis and periodontal disease. I. The oroglanulocytic migratory rate. Periodontics 1968; 6: 207-211.

21) Klinkhamer JM. Human oral leukocytes. Periodontics 1963; 1: 109-117.

22) Klinkhamer JM, Zimmerman S. The function and reliability of the oroglanulocytic migratory rate as a measure of oral health. J Dent Res 1969; 48: 709-715.

23) Woolweaver DA, Koch GG, Crawford JJ et al. Relation of the orogranulocytic migratory rate to periodontal disease and blood leucocyte count. A clinical study. J Dent Res 1972; 51: 929-939.

24）内田武．歯周病の臨床検査としての混合唾液中の白 血球数と潜血量の検討. 日歯周誌 1976; 18: 406-413.

25）中村 晶. 歯周病と唾液因子との関連性の解析（第 3 報)。 日歯周誌 2002; 47: 155.

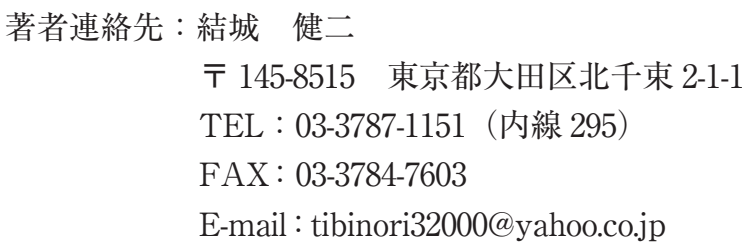




\title{
Establishment of Simultaneous Measurement Method of 8 Salivary Components using Urinary Test Paper and Clinical Evaluation of Oral Environment
}

\author{
Yuuki Kenji, Tsukasaki Hiroaki, Kawawa Tadaharu, Shiba Akihiko and Shiba Kiyoko* \\ Department of Prosthodontics, Showa University School of Dentistry \\ *Graduate School of Health Sciences, Tokyo Medical and Dental University
}

J Jpn Prosthodont Soc 52: 340-349, 2008

\begin{abstract}
Purpose: Clinical findings were compared with glucose, protein, albumin, bilirubin, creatinine, $\mathrm{pH}$, occult blood, ketone body, nitrite, and white blood cells contained in whole saliva to investigate the components that most markedly reflect the periodontal condition.
\end{abstract}

Material and Method: The subjects were staff of the Prosthodontics Department, Showa University, and patients who visited for dental treatments (57 subjects in total). At the first time, saliva samples were gargled with $1.5 \mathrm{ml}$ of distilled water for 15 seconds and collected by spitting out into a paper cup. At the second time, saliva samples were collected by the same method. At the third time, saliva samples after chewing paraffin gum for 60 seconds were collected by spitting out into a paper cup. Thus whole saliva collecting that was divided on three times. After sampling, $8 \mu \mathrm{l}$ of the saliva sample was dripped in reagent sticks for the 10 items of urinary test paper and the reflectance was measured using a specific reflectometer. In the periodontal tissue evaluation, the degree of alveolar bone resorption, probing value, and tooth mobility and the presence or absence of lesions in the root furcation were examined and classified into 4 ranks. The mean values in each periodontal disease rank and correlation between the periodontal disease ranks and the components were statistically analyzed.

Results: Bilirubin and ketone body were not measurable. The components density of the 8 items was increased as the periodontal disease rank increased. Regarding the correlation between the periodontal disease ranks and the components, high correlations were noted for protein, albumin, creatinine, $\mathrm{pH}$, and white blood cells.

Conclusion: The simultaneous measurement method of 8 salivary components using test paper may be very useful for the diagnosis of periodontal disease of abutment teeth.

\section{Key words}

saliva, periodontal disease, saliva examination, abutment tooth 